\title{
Federal Policy Activity and the Mobilization of State Lobbying Organizations
}

\author{
Frank R. Baumgartner \\ Department of Political Science \\ Pennsylvania State University \\ University Park, PA 16802 \\ Virginia Gray \\ Department of Political Science \\ University of North Carolina at Chapel Hill \\ Chapel Hill, North Carolina 27599 \\ David Lowery \\ Department of Public Administration \\ University of Leiden \\ Leiden, The Netherlands 2300RB
}

Paper presented at the annual meetings of the American Political Science Association, Chicago IL, August 30-September 2, 2007. Copyright by the American Political Science Association. 


\begin{abstract}
The mobilization of organized interests is affected not only by social and economic "supply" factors but also by government-related “demand” factors as well. We add to a growing literature noting the impact of government activity on the mobilization of interests by examining how federal policy activity stimulates subsequent lobbying activity at the state level. Empirically, we do this by introducing the federal hearings data used by Leech et al. (2005) into the model of state lobbying registrations used by Gray et al. (2005). We find that Congressional hearings in a particular issue-area have significant effects on the mobilization of state interest organizations in that same area. The effects appear to be stronger in those issue-areas with greater federal involvement and in those states with more professionalized legislatures. Our paper adds to a large literature on how policies can create their own politics, and to a growing literature on the coevolution of groups and the state. We emphasize the intergovernmental aspects of these dynamics here; federal level activities affect the mobilization of interest groups not only at the federal level, but in the states as well.
\end{abstract}




\section{Federal Policy Activity and the Mobilization of State Lobbying Organizations}

Demand for lobbying can be created by government. ${ }^{1}$ Traditionally, scholars have looked at social, demographic, economic and other "bottom-up" factors in explaining the mobilization of interest organizations. Truman, Olson, and others focused our attention on such factors as social disturbances, economic growth and trade, and collective action dilemmas as the most important elements determining the growth and development of interest-group communities. Increasingly, however, scholars have recognized that government activity, far from being only the result of lobbying activity, can also be its cause. As government becomes involved in more areas of the economy, those affected by these activities mobilize. Some do so defensively because they seek to avoid further encroachments and others work proactively because they are involved in the new policies, interacting with government agencies. In either case, policy creates interests. Heinz and colleagues defined an interest group in this way:

It is at the intersection of public policy and the wants and values of private actors that we discover interests. What we call the interests of the groups are not simply valued conditions or goals, such as material riches, moral well-being, or symbolic satisfaction. It is only as these are affected, potentially or in fact, by public policy, by the actions of authoritative public officials, that the valued ends are transformed into political interests that can be sought or opposed by interest groups. $(1993,24)$

In short, public policy is a source of interest organization mobilization.

Accordingly, as government activity expands into areas previously not the objects of any public policy activities, interests are created and interest organizations are mobilized. Jones and Baumgartner (2005) documented substantial increases in the range and scope of federal government activity across the post-1947 period, and the growth of government is well known. The result of this is that many social or economic organizations that may once have had no interest in public policy and that did not lobby have become active as public policy has expanded to affect them. For any given interest organization, this governmental activity may be either welcome or viewed with hostility. In either case, organizations that

\footnotetext{
${ }^{1}$ We appreciate the support of Galen Irwin in helping to facilitate our collaboration. Baumgartner acknowledges the support of National Science Foundation grants \# 0111611 and 0111224 for data collection and Bryan Jones and Beth Leech for related research projects from which this paper draws.
} 
once were just "associations” or institutions such as business firms have become "interest organizations" as their "private wants" have intersected with "public policy.” Note that the mobilization of interest groups may involve their creation where none existed before or it may take the form of involvement with public policy matters by organizations that previously had no contact with government. In either case, the resulting population of interest groups is related to the scope of government activity.

The responses of institutions, groups, and associations to the increased scope of public policy are seen in many ways. Long-term social mobilization is apparent as thousands more interest organizations are active now than two generations ago. The "interest-group explosion” noted by Berry and others was mostly a social or private economics phenomenon, to be sure. It stemmed more from social movements and/or economic diversity than from government "pull” factors, certainly. But, once established, these newly mobilized organizations sought to monitor or to influence the future growth and development of those programs that affected them. Environmental, civil rights, and other examples of organizations immediately come to mind. Women's organizations grew in the 1960s and 1970s, leading to increased involvement by the federal government in anti-discrimination policies. While some elements of the women's movement faded from the scene, other organizations maintained keen interest in the continued functioning of these anti-discrimination policies they helped to create. Arms control and nonproliferation organizations developed in the 1970s, and the continued urgency of these matters keeps them active. Baumgartner and Mahoney (2004) documented such coevolutionary linkages between group and state mobilizations in several issue-areas including the environment, civil rights, elderly, and human rights fields in addition to the women's movement. Clearly, there is surely a long-term link between public policy and the mobilization of interest organizations. The period of greatest growth in the size and scope of the U.S. government (the period surrounding 1970) is the same as the period when the "interest-group explosion” was at its height. In the period since the late-1970s when the growth of government programs has slowed, so too has the rate of growth in the interest-group population (see Baumgartner and Jones 1993, ch. 9). Of course, these general trends mask significant variation by issue-area. 
Many scholars have noted the political effects of large public policies; the development of the social security program has caused its beneficiaries to be particularly attuned to its continued financial viability, according to Andrea Campbell’s (2005) analysis of the policy feedback effects of social security and the mobilization of the elderly. Campbell suggests that the mobilizational effect of dependence on social security is strong enough to undercut the traditional social class bias which disempowers the relatively poor elderly. Similarly, Mettler's (2005) work on the GI Bill and other programs benefiting the "greatest generation" powerfully affected the political behavior of an entire cohort of Americans. Theda Skocpol's (1992) work has similarly focused on the role of the state as the catalyst for the mobilization of groups. Jack Walker discussed at least two important ways in which government activity affects groups. First, in discussing policy diffusion across the states, he placed emphasis on the development of national policy communities and the patterns of professional communication that take place there (1969). The development of policy networks surrounding new public programs is an important part of the coevolution of states and groups that we explore here. Second, Walker (1991) discussed the role of government as a patron or catalyst for the creation of new groups, documenting empirically that a large percentage of groups, especially in the social services domain, benefited from government support or grants and contracts in their early years. Financial support from the government or private foundations was an important element in shaping the interest-group community, he showed. Similarly, Walker brought attention to the growth of government in general to the development of the group system. In sum, many authors working from a long-term perspective and taking either a quantitative or a qualitative approach to the question have shown a strong linkage between group mobilization and government activity.

A shorter-term element is also apparent. Leech et al. (2005) noted that congressional hearings were systematically related to the number of organizations registering to lobby at the federal level, after controlling for economic and other factors expected to account for mobilization. This analysis was based on patterns of lobby registration across 74 issue-areas in repeated six-month time periods. During those periods with more congressional hearings, more organizations were registered to lobby. Policy activity 
stimulates lobbying; the relationship is clearly multi-directional, but this study showed clear mobilization effects on lobbying communities of federal government activity in a given issue area. In this paper we follow directly on Leech and colleagues’ work by linking the policy agendas data they use, which measures annual fluctuations in congressional policy activity across different tissue-areas to state-level interest-group mobilization in those same policy areas.

Our focus here is on an aspect of the general process discussed above - the mobilization of organized interests at the state level in response to policy activities at the federal level. In a manner parallel to that of Leech et al., we find that federal government activities are associated with the mobilization of interest organizations in those same issue-areas in the states. As in the Leech et al. analysis, we include appropriate controls for potentially confounding factors such as the growth in statelevel economic activity, taking advantage of Gray and Lowery’s previously developed Energy-StabilityArea (ESA) model of state interest system density. We add to their model a number of variables associated with several hypothesized influences of federal hearings. Thus, we control for appropriate baseline conditions to assess the additional impact of congressional hearings on the mobilization of state interest organizations, after controlling for those factors Gray and Lowery previously identified in their work on the growth and development of state interest-group systems. Our findings are strong and consistent in showing the federal effects. There remain a number of unanswered questions about the precise mechanisms through which these stimulation effects occur, points to which we refer in the conclusion and which clearly merit additional research.

This project contributes to the broader literature on vertical policy diffusion, as policy attention is a necessary precursor to policy diffusion. We are not, of course, the first to study this phenomenon. But much of the prior work has focused on specific policy areas with somewhat mixed results (Mossberger 1999; Hecht 2001; Tews, Busch, and Jorgens. 2003; Daley and Garand 2005; Shipan and Volden 2006), though the most recent study of five health and welfare innovations did find vertical diffusion a stronger explanation than horizontal diffusion (Karch 2007). A broader view across multiple policy areas may 
help to reconcile some of these mixed findings. We first discuss several ways in which policy attention at one level of government might be linked to another and consider several different forms it might take. We then introduce the model of state level lobby registrations using 1999 measures of the density of organized interests and a measure of Congressional hearings activity over several years. Several versions of the enhanced pooled state- interest guild model are then tested to isolate the nature of the linkage between Congressional activity and state lobbying. We conclude the analysis by considering further questions about and future analyses of cross-level linkages of state and national policy systems.

\section{National Influences on State Lobbying}

Let us start with the null hypothesis that Congressional activity and lobbying in the states may well be unrelated to each other. It is true that we have seen a growing nationalization of state lobbying communities in the sense that they are all now increasingly responding in the same manner to a common set of predictor variables (Lowery and Gray 1994a). And scholars have noted the significant role of state affiliates of national federations in linking of state and national interest systems (Thomas and Hrebenar 1992; Skocpol, Abend-Wein, Howard, and Lehmann 1993). Yet, despite these observations, state interest communities remain extremely parochial in the sense of being dominated by local rather than national or regional organizations. As of the most recent study in 2002 the vast majority of lobbying organizations were registered in only one state (Wolak, Newmark, McNoldy, Lowery, and Gray 2002). Accordingly, we might well expect that they would be much more attentive to issues in their home states and not to those attracting the attention of Congress.

Even more broadly, it is not clear that state and national policy agendas are so tightly linked. Indeed, we know that states’ policy agendas vary to a considerable degree (Gray et al. 2005). Despite ever more rapid diffusion of innovations, not all states focus on the same issues at the same time. This would simply not be true if all states uniformly reflected a single national pattern of policy attention. But even if state agendas moved together in lockstep, much of what attracts the attention of state legislators may well not be what concerns their national counterparts. This would be especially true for a number of 
issues that are mainly influenced by national policy or on the other hand mainly by state policy. While not part of our analysis, for example, it would seem unlikely that Congressional attention to nuclear proliferation policy would stimulate a great deal of lobbying on this topic in the states. State attention to corrections policy may be partly related to federal concerns, but the states are the primary force behind corrections policy whereas the federal role is very limited. Different policy areas, in any case, feature more or less involvement of the federal government; certainly we should expect limited impact of federal activities on state lobbying behavior in those areas where the federal government plays relatively little role. And last, given Baumgartner and Jones’ (1993) punctuated equilibrium model, legislative agendas are quite sticky, changing only periodically and with some difficulty. If so, then it is not clear that state policy agendas would respond in anything close to a contemporaneous manner to activity at the national level. In sum, there are plenty of good reasons to not expect to find a strong relationship between levels of Congressional policy attention and activity and state lobbying.

On many issues, however, state and national attention is hardly segmented in a classic layer cake fashion (Grodzins 1966). Many presumptively state issues - including regulation of heath maintenance organizations (HMOs), the death penalty, abortion, and even the fate of Terry Schiavo - have been the focus of Congressional attention. Federal actions or inactions on all of these issues take place alongside independent state activity. For others, such as the Defense of Marriage Act of 1996, initial federal activity seems to have stimulated subsequent state legislation. And still other national laws, such as the No Child Left Behind Act of 2001 or the Personal Responsibility and Work Opportunity Act of 1996, seem to reverberate through the halls of state capitols in the years following their passage as states are left to struggle with their many intended and often unintended consequences. All of these subsequent state actions were associated with the mobilization of organized interests, a mobilization process kick-started by some federal activity. Yet, if federal legislative activity and state lobbying are connected to each other, it also seems that such linkages might come in several different forms that go beyond the simple federal cause and state effect suggested until now. 
The first is a simple contemporaneous effect with both levels of government and their systems of organized interests struggling simultaneously with a common policy disturbance. In this view, lobbying activity and legislative agendas at all levels reflect less each other than real policy issues facing society. Truman $(1951,511)$, of course, identified the locus of mobilization in disturbances in society. Organized interests engage in political activity to secure redress on these disturbances. More to the point, it is not obvious that organized interests seek such redress at different levels of government in a purely sequential fashion. Moreover, legislative entrepreneurs at all levels of government have powerful incentives to monitor their constituents’ concerns (Wawro 2000; Weissert 1991; Mintrom 1997). Political parties at all levels too win elections by finding issues on which to campaign (Macdonald and Rabinowitz 2001). If legislators, parties, and organized interests at all governmental levels respond swiftly to the same disturbances in society, then we should see the volume of lobbying activity, or the density of organized interests, and the content of legislative agendas at both the national and the state level changing in a contemporaneous and non-causal manner reflecting the public's concerns.

A second possible form of linkage is as a substitution effect. In this case, policies are pursued in different venues provided by our federal structure of government in a sequential fashion. This idea was noted by Truman (1951: 323) and further developed by Morton Grodzins (1966), who argued that the federal systems can be viewed as a structure with many cracks through which influence may be exercised. Patterns of influence impeded at one level may find opportunities for influence at another. Indeed, state officials often frame their attention to problems as a response to federal inaction. ${ }^{2}$ Thus, in justifying his state’s more rigorous than average environmental laws, former California Governor Gray Davis (2002) noted that, “The federal government and Congress, by failing to ratify the Kyoto treaty on global warming, have missed their opportunity to do the right thing. So it is left to California, the nation's most

\footnotetext{
${ }^{2}$ Another and harsher form of substitution is preemption - when federal action essentially precludes state action on an issue. A good health care example occurred in 1974 when Congress enacted the Employee Retirement Income Security Act (ERISA), which preempts state laws that "relate to" employee benefit programs (including health plans) unless such laws are part of the traditional state function of regulating insurance. We do not examine this form of substitution further since it does not occur all that frequently, concentrating instead on political inaction.
} 
populous state and the world's fifth largest economy, to take the lead.”

But perhaps an even better example concerns health care policy. Following the 1994 failure of President's Clinton's comprehensive health care proposal, federal attention to health care seemed at an impasse. Congress seemed unable to address even less comprehensive health care issues, such as growing criticism of HMOs or the increasing inability of seniors to pay for their prescription drugs. ${ }^{3}$ Scholars such as West, Heith, and Goodwin (1996) and Weissert and Weissert (2002) and journalists such as Johnson and Broder (1996) assigned primary blame for the Clinton fiasco and much of the next decade's stalemate to powerful interests representing the health care industry. As a result of this stalemate, however, the states paid increasing attention to health care policy. Following the demise of the Clinton proposal, many acted by the late 1990s to provide their own prescription drug programs (Gray, Lowery, and Godwin 2007a), to adopt a number of new and rigorous regulations of HMOs (Gray, Lowery, and Godwin 2007b), and to take a number of partial (if usually faltering) steps toward the provision of comprehensive health care to their citizens (Gray, Lowery, Godwin, and Monogan 2005). Whether as a cause or effect of all of this state attention to health care policy, organized interests rapidly shifted their attention from Congress to state capitols. Indeed, the health interest sector or guild in the states grew more rapidly than any other during the 1990s (Lowery, Gray, and Fellowes 2005). The key point, however, is that we might well expect a lack of Congressional activity on an issue to stimulate state-level attention to it on the part of either state officials and/or state interest organizations. The best current example is immigration where in reaction to Congress's failure to act in 2007, over 1100 immigration-related bills have been introduced in the fifty state legislatures thus far this year (National Conference of State Legislators 2007), and 170 of them have been enacted into law (Keiderman 2007); both the passage and introduction numbers are double the those of 2006.

A third and we think more typical relationship between Congressional legislative activity and the mobilization of state lobbying is a stimulation effect reflecting many of the examples we noted earlier.

\footnotetext{
${ }^{3}$ Action on the latter was taken in the Medicare Prescription Drug, Improvement and Modernization Act of 2003.
} 
That is, Congressional activity at time one may lead to state lobbying activity at a later time. Activity in Washington will necessarily stimulate state law making in those situations, such as the "No Child Left Behind Act," where federal acts have significant consequences for state laws and regulations. In other cases, such a linkage may better reflect a diffusion of legislative entrepreneurship, where state legislators see that there is electoral hay to be made in following a path already trail-blazed by a member of Congress. Indeed, state interest organizations may mobilize for similar reasons, learning from watching members of Congress. Congressional legislative activity may also stimulate mobilization of state interest organizations in line with Richard Nathan's cyclical theory of federalism, ${ }^{4}$ whereby those adversely affected by legislative proposals under consideration at the federal level may mobilize in the states to protect themselves. Similarly, those encouraged by the emergence of an issue at the federal level may decide that the time is ripe to push for similar actions in their state. In sum, legislative activity at the federal level may have a strong effect on the mobilization of interests at the state level.

Stimulation may come in two types, direct and indirect. The direct stimulation effect is that organizations mobilize in the states in order to become involved in policy domains where they see that federal activities are increasing; they may want to influence state-level implementation, to counter federal involvement by enacting state policies working in the opposite direction, or they may see federal involvement as a sign that political winds favor a state initiative as well. In any of these cases, whether seeking to amplify, modify, or rectify the federal policy activity, federal activity leads directly to the mobilization of interest organizations. The indirect effect is that federal policy activity may cause increased state-level legislative activity. This law-making activity at the state level naturally increases lobbying activity in association with it. While activity in Washington may ultimately be responsible for mobilization, the more proximate cause is a change in the pattern of policy attention in the states.

\footnotetext{
${ }^{4}$ Nathan argued that when society as a whole favors governmental action in a new field or of a new kind, proponents will find it more efficient to concentrate their energy on achieving policy change at the center. But when there is diminished support for governmental action in the society, i.e., during conservative periods, proponents are likely to be most successful in those states where there happens, for whatever reason, to be support for such action. Thus states will move into policy areas as the national government moves out or does not take initiative.
} 
There are strong reasons to suspect that the third hypothesis, the stimulation effect, is most prevalent. In any case, we can devise simple tests to compare the null, the spurious (contemporaneous), the substitution, and the stimulation hypotheses, and we do so below. To do so, we posit two additional expectations in line with the two mechanisms discussed in the previous paragraph. First, in line with Nathan's expectations, we expect the federal stimulation effects to be stronger in those policy domains where federal involvement is greater than in those where states traditionally act more autonomously. As we noted above, where federal activities focus on foreign affairs, nuclear nonproliferation, or other issues treated exclusively at the national level, this should have little impact. Similarly, states may be involved in regulation of occupations or professions, in regulation of critical functions such as insurance, in running large public enterprises such as prisons where state policy is almost completely independent of any federal policy, as the federal government is not a financial partner in these issue-areas nor is it otherwise involved. Within those issue-areas with greater state-federal partnership (or interference), patterns of communication within professional communities may be more nationalized, and we would therefore expect stronger stimulation effects in these areas. If for no other reason, states are often charged with implementing policy changes adopted at the federal level in such mixed policy domains, and these implementation efforts will attract lobbying activity.

Second, in line with the expectation over the timing of issue attention, the stimulation effect should be stronger in those states with more professional legislatures given that politicians in these states would welcome the appearance of issues - whether supportive or in opposition to federal activity - as a means of promoting their own careers. Legislative entrepreneurship, we have already noted, is an important part of promoting one’s political career in more professionalized political settings whether in Congress (Wawro 2000) or in the states (Weissert 1991). Thus, professional politicians monitor their environment for issues to promote. And one important short-cut to monitoring the policy environment directly is to monitor what other politicians in other legislatures are talking about. Indeed, Mintrom's (1997) analysis of the diffusion of school choice legislation across the states shows strong evidence of 
such policy monitoring. It is a very small step to suggest that such policy monitoring also occurs as a vertical diffusion process across levels of government. Indeed, research on specific policy areas has found of evidence of diffusion of policy innovations running in both directions across nearly all levels of government (Mossberger 1999; Hecht, 2001; Tews, Busch, and Jorgens. 2003; Daley and Garand 2005; Shipan and Volden 2006; Karch, 2007). Indeed, Shipan and Volden (2006), echoing our earlier discussion of the role of legislative entrepreneurship, have found that such vertical diffusion is linked to levels of legislative professionalism. Further, more professional legislatures may have greater staff resources and be more closely connected to activities within national policy communities. So, we would expect the stimulation effects to be stronger in states with more professional legislatures.

If our theory and expectations are correct, we expect stimulation effects to be stronger than the null, substitution, and contemporaneous hypotheses, and these tests are easily conducted. Further, we expect the stimulation effect to be more powerful in certain states and in certain issue-areas, a matter also easily suited to empirical testing. We turn to our empirical approach next.

\section{Exploring State-Federal Linkages}

\section{Data and Operationalizations}

Our empirical approach builds on previously conducted research at both the state and federal

levels. Leech et al. (2005) examined how hearings activity in Congress influences the lobbying activities of Washington interest organizations. Similarly, Gray et al. (2005) showed how the size of state legislative agendas, as measured by bill introductions, influence state lobby registrations. While using quite different measures, both studies find that legislative activity promotes lobbying activity. We examine how national legislative activity influences the demand for lobbying at the state level by introducing the Congressional hearings data from the Policy Agendas Project (www.policyagendas.org) into the model of state lobbying registrations used by Gray and colleagues (2005). More specifically, our analysis builds on Gray et al.’s (2005) test of the Energy-Stability-Area (ESA) model of interest system density using a pooled model with interest guilds and 50 states. Their dependent variable - the main 
focus of our analysis - was lobbying activity as measured by state lobby registrations across 15 interest guilds in 1997. ${ }^{5}$ We measure interest activity with the density of lobby registrations by interest guilds in 1999. The lobby registration data have been described more fully elsewhere (Gray and Lowery 2001). ${ }^{6}$ Not all of the registration data discussed in that earlier study could be used in the Gray et al. (2005) analysis. Of the 26 categories of interest guilds in the population, Gray et al. (2005) excluded several smaller guilds or economic sectors because they could not be readily linked to a guild-specific component of GSP, their measure of the area or supply term of the ESA model. ${ }^{7}$ In the end, they analyzed 16 interest guilds representing banking-finance, construction, communications, hotels and restaurants, agriculture, manufacturing, legal, transportation, insurance, health, utilities, natural resources, education, local government, welfare, and sports and recreation representing 76.09 percent of registrants. ${ }^{8}$ Four additional guilds are dropped from our analysis here (manufacturing, hotels and restaurants, construction, and sports) because they could not be readily matched with an exclusive set of the Congressional hearings data, which we discuss further below. In the end, our pooled analysis examines 12 interest guilds with a total of 22,686 lobby registrations or 61.38 percent of state lobbying communities in 1999.

The key independent variables beyond the hearings measures are the area and energy terms of the ESA model (Lowery and Gray 1995). As the potential membership of an interest guild increases, it is

\footnotetext{
${ }^{5}$ Previous work indicates that the stringency of state lobbying registration requirements has little impact on the density (Lowery and Gray 1997; 1994b) and diversity (Gray and Lowery 1998) of state interest communities. ${ }^{6}$ Briefly, lobby registration lists were gathered by mail or web page from state agencies responsible for their maintenance. After purging the lists of state agencies in states requiring their registration, organizations registered to lobby - rather than individual lobbyists - were coded by organizational type (membership group, institution, or association) and interest content (26 guilds of substantive interests) using directories of organizations and associations and the web pages of individual organizations. A second coder then examined the coding assignments with discrepancies resolved via discussion between the two coders. Only 1.58 percent of the 35,928 organizational lobby registrations in 1997 and a similar number in 1999 could not be coded by type or substantive interest.

${ }^{7}$ These included the organizations in the military/veterans, good government, tax, environment, religion, women's issues, and civil rights guilds. Similarly, the small business and the services-of-business guilds were excluded because of their extreme issue diversity, which made it difficult to identify their discrete interests in the bills being considered by state legislatures. Second, the small police/fire guild was combined with the local government guild. ${ }^{8}$ Interest organizations frequently move on and off state lobby registration rolls as specific issues wax and wane (Gray and Lowery 1995a). For example, 17.35 percent of the interest organizations registered to lobby in the states in 1997 were not registered in 1998. Of those registered in 1998, 27.48 percent were not registered in 1997. Thus, there is considerable churning in state interest systems (Anderson, Lowery, Gray, and Newmark 2005).
} 
expected to support a larger number of lobby registrations. But this relationship is also expected to be curvilinear or density dependent, with the rate of growth of lobby registrations in response to increases in the size of the potential membership of a guild expected to slow, as the size of the potential membership becomes larger. ${ }^{9}$ Gray and Lowery have used a variety of measures in polynomial specifications to test the density dependent impact of variations in the size of the potential membership of guilds across states. ${ }^{10}$ All produce similar findings with the choice among them largely dependent on the availability of data at different levels of aggregation. In this analysis, we need to assess the relationship between the size of the potential membership of guilds and lobby registrations across states and guilds. We opt, therefore, for an intermediate measure of the size of the potential membership of the interest guilds: the 1997 gross state product (GSP) generated by each guild in each state. ${ }^{11}$ Guild-specific GSP is included in a polynomial specification with its nominal value expected to have a positive association with registrations and its squared value expected to generate a negative coefficient.

Lowery and Gray (1995) use two measures of the energy underlying the mobilization of state interest organizations. The first is interest uncertainty. As party competition increases, the likelihood of sudden policy change increases. This uncertainty should encourage both those favored by current policy as well as those disadvantaged by the status quo to engage in political activity. Lowery and Gray tap interest uncertainty with a folded Ranney index of party competition. We measure party competition with a folded Ranney index for the 1995-1998 period (with the values of non-partisan Nebraska as the average of the values of its neighbors). Since this measure is inversely coded, negative coefficients indicate that party competition promotes mobilization. Lowery and Gray’s (1995) second energy term concerns constituent interest, the specific concerns of a guild that are its focus for lobbying. This measure builds

\footnotetext{
${ }^{9}$ Lowery and Gray (2001) report that density dependence results roughly equally from the depression of the birth rates of new registrations and the enhancement of death rates of older organizations in crowded interest systems.

${ }^{10}$ These include very narrow indicators that are highly specific to each guild (Lowery and Gray 1995), intermediate measures such as the number of firms associated with each guild (Lowery, Gray, and Fellowes 2005), and highly aggregated measures such as total GSP in a state (Lowery and Gray 1998).

${ }^{11}$ Guild-specific GSP is strongly correlated with the number of firms in a state associated with the guilds' interests (Lowery, Gray, and Fellowes 2005), another intermediate measure of the area term of the ESA model.
} 
on the strategy originally pioneered by Bowling and Ferguson (2001), measuring constituent interest by the size of the issue agenda of concern to each guild by the number of bills considered in state legislatures in 1999 tapping issues of concern to it. ${ }^{12}$ The bill count data was collected from the "State Full Text of Bills” database on Nexis Academic Universe. ${ }^{13}$ In most cases, we used their search terms to code the number of times that a state bill was considered with content germane to each guild's interests. ${ }^{14}$ In some cases, however, additional subject search terms were created when the provided search terms did not include a term corresponding with our guild topics. The finance guild, for example, includes both banks and real estate organizations. In such cases, multiple search terms were employed to tap this diversity. ${ }^{15}$

\footnotetext{
${ }^{12}$ Several measures of state agendas were considered. Ferguson (1996) measured the governor's legislative agenda in all 50 states through a content analysis of the 1994 "state of the state" speeches. Fording, Woods, and Prince (2002) analyzed thirty-seven 1999 "state of the state" speeches, identifying nine different policy initiatives pursued by governors. Perhaps the measure best matching our needs is Gerald Wright's collection of roll call data for all 7,424 legislators between 1999-2000 (Wright and Winburn 2002). While each of these measures of legislative agendas has virtues, our analysis requires a measure of legislative activity in many different issue areas, a level of specificity that is not reached by extant measures. Further, we required a measure of the entire state legislative agenda, and not only bills of high priority to governors or those with roll calls. Given that we spend a considerable part of this analysis considering contemporaneous and lagged effects of the hearings variable, some might ask about the exclusively contemporaneous inclusion of the bill count data in the ESA model as our measure of agenda size. However, Lowery, Gray, and Fellowes (2005) fully examined a variety of specifications for the agenda size variable, finding that a simple contemporaneous inclusion clearly proved to be the superior specification.

${ }^{13}$ The database is maintained by LexisNexis, a division of Reed Elsevier Inc, and is available at http://www. nexis.com. The database contains bill text files for all bills considered by each statehouse in a calendar year and provides a separate listing for each revised version of a bill in the database. For example, Alabama House Bill 175, which appropriated \$4,564,831 to the Department of Public Health in 1997, was listed five times in the database: one entry was the introductory version, three were revisions, and the fifth was the enacted bill. Each bill is assigned a set of subject codes at the time of consideration.

${ }^{14}$ Alternative coding modes were considered, including keyword text searches and bill summary searches. But these were deemed to be infeasible or unreliable because of database limitations.

${ }^{15}$ The search terms for the 15 guilds were as follows, with the search terms in parentheses: Agriculture (agriculture), Finance (banking, real estate), Communications (media, telecommunications), Construction (construction), Education (education), health (health), Insurance (insurance), Law (legal), Local Government (municipality, public employees, police, fire), Manufacturing (manufacturing), Natural Resources (gas, oil, minerals), Transportation (highways, transit, airports), Utilities (utilities), and Welfare (social services, charities). Two issues concerning our measure of the size of the policy agenda facing each interest guild deserve further comment. First, we do not believe that the search terms provide a comprehensive count of all of the bills the several guilds attend to as they lobby state legislators. Rather, the measure is designed to tap variations in legislative activity across states and across guilds. After reviewing the issue counts, we are quite confident that they tap this variation. States with extensive natural resources, for example, generated much higher bill counts than those without oil, natural gas, or mining industries. Second, as noted earlier, some bills are counted more than once if they were revised as they moved through the legislative process. Rather than a drawback, we view this aspect of the coding scheme as quite appropriate for our purpose. That is, the attention of organized interests should be heightened as bills proceed further on the road toward becoming law. Our coding scheme taps this greater energy. In 1999, the average guild in the average state generated 117.72 bill counts with a standard deviation of 179.41.
} 
So far, all of the measures were employed by Gray et al. (2005) in their analysis of the demand for state interest organizations. The critical innovation of this analysis is the inclusion of data on Congressional hearings as used by Leech et al. (2005). At the federal level, lobbyists must disclose their activities in each of 74 different policy domains. Leech and colleagues took the numbers of Congressional hearings as compiled in the Policy Agendas Project and matched them with as many of these 74 issue-areas as possible. The Policy Agendas Project categorizes hearings into 226 distinct subtopics, and Leech and colleagues were able to establish fits for about two-thirds of the policy topics, covering 85 percent of the lobbying activity. Here we do the same thing for the state interest guilds as previously identified by Gray et al. (2005). Appendix 1 shows the correspondences between the agendas data and the interest guilds. Twelve guilds are used in the analysis, together representing 22,686 or 61.38 percent of the total number of lobby registration by organizations in the states in 1999.

We examine two sets of measures of Congressional hearings: 1998 and 1999. Generally, we expect the 1999 hearings measure to tap a contemporaneous impact of policy issues on federal and state agendas given that there would have been no time for federal activity within 1999 to diffuse to state level mobilization of organized interests in the same year. In contrast, we expect the 1998 hearings measure to tap a vertical diffusion process, whether in the form of a substitution or a stimulation effect given that time would have allowed for a lagged response of one level of government to the other. In practice, however, we will see that sorting out these effects is somewhat difficult given that 1998 and 1999 hearings are correlated at the 0.95 level. We also examined longer lags with hearings data from 1996 and 1997 and we also examined combining the annual measures into biannual counts over four years. These longer lags had little impact on our findings. Thus, we do not report these results.

Our theoretical analysis also suggested several possible interactions. We suggested that impact of federal hearings on the mobilization of state interest organizations might be especially great in policy areas where federal involvement is higher and in states with professional legislators who might have strong incentives to act as policy entrepreneurs. We use quite straightforward measures of each, although 
we will see that they generate very strong findings. We measure federal involvement with a simple dummy variable scored one identifying five of the 12 policy areas - health, agriculture, education, transportation, and welfare - as more strongly influenced by federal policy activity than the others listed in Appendix 1. Our judgment is based upon the extent to which the federal hearings listed in the Policy Agendas Project indicated that federal financial support or federal regulations would substantially assist, overlap with or interfere with similar programs operated by state governments. In Agriculture the hearings covered farm subsidies, agricultural trade and exports, the plight of the family farm, and the status of the migrant worker, all areas that affect farm programs operated by state governments. Education hearings coded by the Policy Agendas Project took up a wide variety of topics that vitally affect state education policy at all levels, from Head Start to bilingual education, special education, foreign language training, science education, testing and performance standards, programs for the gifted and talented, distance education, desegregation of schools, charter schools, funding of libraries, arts and humanities education, the Elementary and Secondary Education Act, and a variety of programs in higher education including loans and grants to students, the GI bill, construction funds for college buildings, and NDEA funding. Federal hearings in the domain of health considered numerous issues that impact the states' ability to reform their health care systems, e.g., the impact of ERISA on the regulation of HMOs, as well as the Medicaid program, and the rising cost of prescription drug coverage (31 states have such programs for seniors). In the transportation area the federal hearings focused on issues of interest to states such as the interstate highway program, federal aid for highway construction, mass transit grants, maintenance funds for bridges, beautification of highways, speed laws, and drunk driving laws. In the welfare area the Congress completed its conversion of the AFDC program to the TANF program, a major overhaul of state welfare programs, changing their entitlement programs to block grants and time-limited programs. Also hearings were held on child nutrition and women's programs of interest to states. In comparison, the seven remaining policy domains that are a match between the Policy Agendas Project and the State Lobbying Project are policy areas in which the actions of the federal government 
and state governments are not tightly linked. These seven domains are: banking and finance, communications, government, insurance, law, natural resources, and utilities and energy policy. In most of these domains the federal government regulates private behavior; it is not a funding source, nor a joint regulator. The one exception is Government Operations, which refers to federal government procurement, efficiency and the like, but again not an activity that impacts state governmental operations. Our theoretical framework also presumes that state legislative professionalism is one of the mechanisms through which vertical diffusion operates as professional state legislators want to emulate the policy agendas of their Congressional peers. After consideration of the extant measures of state legislative professionalism (Berry, Berkman, and Schneiderman 2000; Kurtz 1992, King 2000; Squire 1992) and guided by Mooney (1994), we elected to employ Squire’s measure updated as of the late 1990’s (Squire and Hamm 2005). It uses the U.S. Congress as a baseline against which to measure the salary, staff and time in session of all fifty state legislatures. California ranked first on Squire's index and New Hampshire ranked last in professionalism, which seems to lend face validity to the measure. The federal involvement dummy and the Squire index, as well as their interactions with the 1998 hearings measure, are included following presentation of baseline models.

While the main part of our analysis will focus on the direct impact of federal hearings frequency on lobbying registrations in the states, we will also conduct an additional set of tests of the indirect effects of hearings on state lobby registrations through their impact on the size of state legislative agendas. That is, federal hearings activity may lead state legislators to introduce bills on the subjects of the hearings, which would in turn be expected to influence state lobby registrations given the logic of the ESA model. The dependent variable in this second set of tests is agenda size as measured by bill counts, which we have already discussed as one of the energy terms of the ESA model. The key independent variables in this analysis are the Congressional hearings measure and their interaction with federal activity and state legislative professionalism, as just discussed. To control for rival explanations of bill introductions, we include a full array of state dummy variables in these models, although these are not reported. We will 
finally look at the combined direct and indirect effect of lagged hearings.

\section{Findings}

Table 1 presents the baseline and enhanced ESA lobbying registration models without inclusion of dummy controls for states except for the last column. Looking initially at these simpler models is essential, we think, to assess the robustness of the model given potential problems of collinearity associated with the state dummies. That is, the party competition variable varies only over states, not interest guilds. And the agenda size and hearings measures vary only over guilds, not states. Using dummy controls in these situations, thus, risks rather severe collinearity problems. But we will see later that introduction of the state dummy controls do not alter our findings. The first model in the table presents a baseline predictor of state lobby registrations without inclusion of the federal policy activities measure. The linear GSP term is, as expected, positive and significant in the baseline ESA model as well as in all of the models including variants of the Congressional hearings measure. Also as expected, the squared GSP estimates are uniformly negative and significant, indicating that density dependence sets in as interest systems become large. Similarly, the party competition estimates are negative and significant, indicating - given inverse coding - that registrations increase with competition. And the size of the state policy agenda - as measured by bill counts - generated positive, significant estimates. These results are as expected and provide strong support for the ESA model. ${ }^{16}$ But this is not a new finding and we will, therefore, have little further to say about the ESA coefficients given that they are included in the models to provide the necessary context within which to assess the impact of the federal hearings variables.

(Insert Table 1 about here)

Models 2 and 3 in table 1 show, respectively, the impact of contemporaneous Congressional hearings in 1999 and lagged hearings in 1998 on state lobby registrations in 1999, controlling for the ESA model variables just explained. Federal hearings add only modestly to the overall predictive power of the two models, but both the 1999 (model 2) and the 1998 (model 3) variables are highly significant and both

\footnotetext{
${ }^{16}$ One-tailed tests are used for the ESA model variables given strong prior expectations about them.
} 
are positive, indicating that Congressional hearings promote state lobby registrations. To distinguish between the contemporaneous effect of the 1999 hearings measure and the stimulation effect of the lagged 1998 measure, both are included in model 4 of the table. The estimate for the contemporaneous 1999 measure switches sign to negative. But the more important consequence of including both the 1998 and 1999 measures is that neither is now discernibly different from zero, precluding our ability to reject the null hypotheses that Congressional hearings have no impact on state lobbying registrations. We have already noted, however, that the two measures are very strongly correlated ( $\mathrm{r}=0.95)$. Thus, it is likely that collinearity is preventing us from distinguishing their effects. But given the strong positive estimates for both in models 2 and 3 and the fact that the positive estimate for the lagged 1998 variable in model 3 approaches standard significance criteria ( $\mathrm{t}=1.61)$, we will continue to include it in the model. We will, however, reconsider this decision below in our discussion of model 6. At this point, then, model 3 seems to provide the best specification and indicates that federal hearings do indeed stimulate state lobby registrations in a direct manner when controlling for the standard ESA variables. Our comparison of models 2 and 3 suggests that the stimulation effect (model 3) is more powerful than the potentially spurious explanation associated with the contemporaneous effect (model 2). The substitution effect - a negative relationship between federal activities and state mobilization - receives no support.

In model 5, we include measures and interaction terms designed to distinguish policy areas with greater federal policy involvement and states with greater legislative professionalism. Inclusion of both variables and their interaction terms requires that we interpret our results carefully. Hearings in 1998 now show a slight negative relationship with lobby registrations $(b=-0.15)$ as compared to a slightly stronger positive relationship in the basic model $3(b=0.16)$. However, the interaction with areas of federal influence has a positive coefficient of 0.58 , suggesting that the overall effect is highly positive for those issue areas with strong federal involvement, negative for those with little federal involvement. Similarly, the interaction between hearings and legislative professionalism is positive (0.11) as well, albeit weakly so at only the 0.10 level. Still, this suggests that those states with more professional legislatures respond 
significantly more strongly to federal government activities. These complicated interactions create some issues of collinearity in our models (as, for example, the states with highly professional legislatures also tend to be those with the greatest GSP values, an essential control in the ESA model). But the overall picture laid out in Table 1 is clear. Model 3 suggests that there is a stimulation effect. Model 5 makes clear that the patterns of interaction differ significantly, and indeed are opposite in impact, in professional as opposed to nonprofessional legislatures and in those issue-areas with greater federal involvement versus those where the states are relatively autonomous. These findings suggest, reasonably enough, that state-level lobby registrations by organized interests can be affected by federal policy activity but that the effect is much stronger in certain states and in certain issue-areas than others. ${ }^{17}$

The results in model 5 include only the lagged 1998 hearings given the lack of discernible estimates in model 4 when both 1998 and 1999 hearings variables were included in the model. Model 6 is similar to model 5, but now reinserts the 1999 hearing variable to check whether their exclusion in model 5 based on considerations of collinearity was premature. It seems that it was. While all of the other estimates remain essentially the same, both the 1998 hearings estimate and the 1999 hearings estimate are significant in model 6. And their respective signs - positive for the 1999 estimate and, consistent with model 5, negative for the 1998 estimate - suggest that federal policy activity has a very complex influence on lobby registrations. The most plausible interpretation of the positive 1999 estimate is that both federal and state policy systems are responding contemporaneously to policy events in the real world. This effect now seems to be independent of the mix of stimulus and substitution effects associated with lagged 1998 hearings and its associated interactions with state legislative professionalism and the

\footnotetext{
${ }^{17}$ This complex interpretation was confirmed in additional analysis where model 2 was run separately under four conditions: 1.) nonprofessional legislature (with the Squire indicator dichotomized into high and low levels of professionalism) and low federal activity, 2.) nonprofessional legislature and high federal activity, 3.) professional legislature and low federal activity, and 4.) professional legislature and high federal activity. The standardized estimates of the 1998 hearings variables were, respectively, $-0.12(\mathrm{t}=-2.71), 0.34(\mathrm{t}=4.97),-0.15(\mathrm{t}=-1.13)$, and 0.63 $(\mathrm{t}=3.49)$. Hearings had: 1.) a negative, significant impact in low professionalism-low federal activity conditions, 2.) a slightly negative impact in high professionalism-low federal activity conditions, albeit not significant, 3.) a modest but significantly positive impact in the low professionalism-high federal activity condition, and 4.) a very strong positive impact in the high professionalism-high federal activity condition.
} 
level of federal policy involvement. ${ }^{18}$ Last in regard to table 1, model 7 is similar to model 6, but includes 49 state dummy variables to probe the robustness of the model in the face of naïve controls for other state-level influences on state lobby registrations. The results are very similar to those presented in model 6 with perhaps only two points worth noting. First, the estimate for the party competition variable is no longer significant. This is almost certainly due to the inclusion of the state dummies since the party competition variable - along with several others - varies only by state. And second, the interaction of professionalism and 1998 hearings, which was positive but only weakly significant in models 5 and 6 , now generates a positive estimate (0.14) that is significant at the 0.01 level.

We will return to considering the net effect of lagged hearings in a moment. But first, we have also noted that Congressional hearings may also have an indirect impact on state lobby registrations by stimulating bill introductions in state legislatures, which in turn stimulates registrations in the manner specified by the baseline ESA model. We test this expectation in table 2, which reports the results from regressing 1998 and 1999 federal hearings and their interactions with state legislative professionalism and federal responsibility on our measure of the size of state policy agendas (bill counts) in 1999. Obviously, this is far from a complete specification. Still, while their estimates are not reported, our specification also included a full set of state dummy variables to control - if in a naïve manner - for other state-level determinants of legislative activity (Gray and Lowery 1995b).

(Insert Table 2 about here)

The results of the first model with only the 1999 hearings variable provides little evidence of a contemporaneous impact of federal hearings on the size of state agendas. The estimate of the 1999 Congressional hearings in model 1 is positive, but generates an estimate that is smaller than its standard error. In contrast, inclusion of the lagged 1998 hearings variable in model 2 generates a significant positive estimate, indicating that Congressional hearings in one year have a positive or stimulative

\footnotetext{
${ }^{18}$ We also tried to examine the interactions of federal responsibility and legislative professionalism with the contemporaneous 1999 measure of hearings. At that point, however, collinearity became overwhelming.
} 
influence on state bill introductions in the following year, which then promote lobby registrations. Still, as seen in model 3, both a lagged stimulative and a contemporaneous substitution effect are evident when agenda size is regressed on both 1998 and 1999 hearings. The former is positive, suggesting that more Congressional hearings in one year are associated with a larger state policy agenda in the following year. But the latter is positive, suggesting that within any one year, more federal attention to an issue via hearings suppresses the size of the state policy agenda in that policy domain in that same year. This is the opposite of the results in model 1 , suggesting that activity of organized interests and bill introductions may not be fully in sync over time (but see: Lowery, Gray, and Fellowes. 2005a).

Both the positive 1998 and negative 1999 hearings estimates are also evident in model 4, which includes the federal influence and state legislative professionalism measures and their interactions with 1998 hearings. Both coefficients for federal influence and the two legislative professionalism estimates are significant and signed in a manner that is consistent with results reported in model 7 of table 1 . In general, greater federal involvement in a policy area suppresses the size of the state agenda in that domain as measured by bill counts. However, when Congress holds more hearings, this is reversed so that states in the following year face a more crowded policy agenda. Further, lagged federal hearings in general have an indirect stimulative impact on state lobby registrations through their impact on the size of state policy agendas $(\mathrm{b}=-0.37)$. In sum, federal hearings activity has an indirect impact on the size of the lobby community via a similarly complex set of relationships as observed for the direct impacts.

So, how do these complex direct and indirect federal influences combine to influence lobby registrations in the states? Answers are provided in figure 1, which reports the predicted number of lobby registrations for an interest guild under varying conditions of number of lagged (1998) Congressional hearings, levels of state legislative professionalism, and level of federal policy involvement. These estimates were generated using the estimates reported in the last model in table 1 and setting most of the ESA variables (GSP, GSP-squared, and party competition) at their means. We then varied number of Congressional hearings, levels of legislative professionalism, and level of federal policy involvement 
across their means, plus one standard deviation, and minus one standard deviation, respectively. These changes tap the direct impacts of federal hearings activity on state lobbying activity. We also, using the results in the last column of table 2, varied the values of state policy agenda variable in the core ESA model for the several conditions of these three independent variables. This taps the indirect impacts of Congressional hearing activity on lobby registration as expressed through the size of state policy agendas. Thus, the first set of three bars in the figure show the expected number of lobby registrations for an interest guild holding all variables at their means (including professionalism and federal involvement), but using the mean, plus 1sd, and minus 1sd estimates of number of federal hearings, respectively, and the associated values for size of state policy agenda. The following sets of three bars indicate the same results but under conditions of minus 1sd and plus 1sd in levels of legislative professionalism and minus 1sd and plus 1sd in levels of federal involvement, respectively.

(Insert Figure 1 about here)

Three results of this figure are noteworthy. First, for states with average levels of legislative professionalism and interest guilds with average levels of federal involvement, higher than average numbers of hearings do not greatly increase lobbying registrations (31.53) over baseline (31.53). Yet, lower than average levels of hearings lead to very low levels of lobby registration. This suggests that lagged hearings have a modest stimulative effect. But there are powerful interactions in the analysis.

Thus, second, the highest bar in the figure (61.14) is under the condition of higher than average hearings in states with professional legislatures. This really stands out in comparison to the other values in the second and third sets of comparisons. And it stands in sharp contrast to the weak substitution effect of federal hearings in the low professionalism condition, where higher than average numbers of lagged hearing produced an estimate of only 26.96 registrations while fewer than average hearings generated an estimate of 33.07 registrants.. Simply put, more hearings in one year stimulate lobby registrations in states with professional legislatures in the following year. In sum, greater than average numbers of hearings add to the usual or baseline numbers of interest organizations registered to lobby in states with 
professionalized legislatures. The opposite, if a somewhat weaker effect, occurs in state with low levels of legislative professionalism.

The third key results to note concern the powerful interaction between numbers of Congressional hearings and levels of federal policy involvement. In areas of low federal involvement, fewer federal hearings are associated with higher number of lobby registration: 46.92 in the low hearings condition and only 17.10 in the high hearings condition. The opposite occurs in the high federal involvement condition; higher than average number of Congressional hearings produce an estimated 46.27 lobby registrations while lower than average hearings produced only 15.40. In the former case, low federal involvement in general and few hearings in specific indicate a policy area that is likely to be fundamentally a state concern and one in which that national government has chosen to avoid. As a result, we might well expect more lobbying activity at the state level. Still, the very low number of registrations (17.10) under the condition of low federal involvement and high numbers of Congressional hearings is a bit surprising. One possibility is that this reflects something of a substitution effect with the causality operating in a consistent if mirror image of the health care example of a substitution effect discussed earlier. That is, we might see Congressional hearings in some troubled policy areas in which the national government is not normally involved, but in which there is also little policy activity - and thus relatively few organized interests - at the state level. Congressional hearings on race relations in the 1950s might provide an example of such a substitution effect where the Congress is acting in substitute for state policy makers. But under the high federal involvement condition, the impact of hearings is obvious and operates in the expected manner. When the Congress holds hearing on issues in which they exercise considerable influence, state lobbying activity increases markedly in the following year.

\section{Conclusion}

Scholars have recently turned their attention to closer analysis of the demand function for lobbying by studying how political activity on the part of organized interests is stimulated by legislative agendas (Leech et al. 2005; Gray et al. 2005). We extended these analyses by examining several ways in 
which policy agendas at the national- and state-levels might be linked so as to stimulate or inhibit the mobilization of organized interests in the states. Our results support several conclusions, all of which point to various ways in which the growth and development of policy activities at the federal level do indeed affect state-level interest group mobilizations. The precise mechanisms and timing associated with these factors should be the object of further research, but the general effects are clear: strong linkages exist between federal policy activities and the subsequent activities of groups in the states.

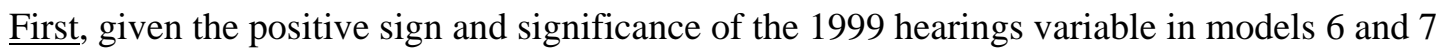
from Table 1, we have evidence of a contemporaneous direct response to on-going events in the political world at both levels of government. We have not highlighted this impact in our discussion of figure 1, which emphases the direct and indirect impacts of lagged hearings, but it is one of the most important of our results. Lobbyists at the state level and members of Congress through hearings are both reacting to the same things; given their powerful incentives to do so, there is no reason to expect them to fail to react to common problems and opportunities.

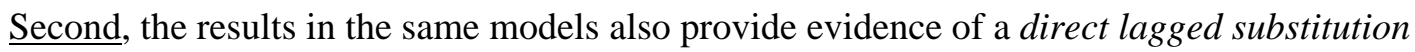
effect. That is, the negative and significant estimate of the 1998 hearings suggests that Congressional hearings in one year dampen state lobby registrations in the following year, at least in certain states (those with the least professionalized legislatures) and in certain policy areas (those with the least federal involvement). But the more powerful impact is through stimulating even greater than baseline lobbying activity in states with professionalized legislatures and in policy areas with higher than average levels of federal involvement.

Third, the results in table 2 suggests that Congressional hearings have indirect lagged stimulation and indirect contemporaneous substitution effects on state lobbying activity though their impacts on the size of state policy agendas. These effects of the lagged (1998) and contemporary (1999) hearings variables are the opposite of those observed for the direct effects on lobby registrations. This suggests that it takes time for changes in levels of federal activity to work their way into patterns of bill 
introductions in the states to which then organized interests then respond. But fourth, levels of professionalism in state legislatures and levels of federal involvement with policy areas influence these indirect (through the size of state policy agendas) effects in the same manner as observed with the direct effects. That is, the size of state policy agendas react more positively to lagged Congressional hearings in states with professional legislatures and in policy areas in which the federal government plays a strong funding and/or regulator role.

The broader interpretation based on all of these results is that state lobby registrations seem to have a very complex direct and indirect response to Congressional hearings activities. More generally still, our results suggest that the processes that govern vertical policy diffusion are many and distinct. In all, these findings provide strong and robust support for the view that organized interests are strongly affected not only by the "bottom-up" factors that have long been studied in the literature and which are reflected in the supply and area variables in the ESA model, but also by the "energy" factors as well. The uncertainty of the state legislative environment, the degree of policy activity in the state, both long- and short-term levels of policy activity apparent at the federal level, and especially the connections among these factors are important forces in stimulating organizations to mobilize either to protect themselves from initiatives they oppose or to take advantage of opportunities to shape new policies they support. But only under certain conditions, an observation that is impossible to derive from studies of diffusion focusing on a single policy. If a diffusion of policy attention is a necessary prerequisite for diffusions of policy innovations, then a broader consideration of the multiple pathways in which federal policy attention influences state-level policy attention in the manner examined here is needed in further studies of the vertical diffusion process. Organized interests react to their environments. Because other levels of government and their activities are a large part of the environment, properly specified models of interest mobilization and the diffusion of policy attention must include measures of government activity. 


\section{References}

Anderson, Jennifer, Adam Newmark, Virginia Gray, and David Lowery. 2004. “Mayflies and Old Bulls: Demographic Volatility and Experience in State Interest Communities,” State Politics and Policy Quarterly, 4 (2): 140-160.

Baumgartner, Frank R. and Bryan D. Jones. 1993. Agendas and Instability in American Politics. Chicago: University of Chicago Press.

Baumgartner, Frank R. and Christine Mahoney. 2004. Social Movements and the Rise of New Issues. In Routing the Opposition: Social Movements, Public Policy and Democracy. Eds. Helen Ingram,Valerie Jenness and David S. Meyer. Minneapolis: University of Minnesota Press, pp. 6586.

Berry, William D., Michael B. Berkman, and Stuart Schneiderman. 2000. “Legislative Professionalism and Incumbent Reelection: The Development of Institutional Boundaries.” American Political Science Review. 94:859-874.

Campbell, Andrea L. 2005. How Policies Make Citizens: Senior Political Activism and the American Welfare State. Princeton, NJ: Princeton University Press.

Bowling, Cynthia J. and Margaret R. Ferguson. 2001. "Divided Government, Interest Representation, and Policy Differences: Competing Explanations of Gridlock in the Fifty States.” Journal of Politics 63:182-206.

Daley, Dorothy M. and James C. Garand. 2005. “Horizontal Diffusion, Vertical Diffusion, and Internal Pressure in State Environmental Policymaking, 1989-1998.” American Politics Research, 33: 615-644.

Davis, Gray. 2002. “California Takes on Air Pollution and Greenhouse Gases.” Washington Post. July 22, p. A15.

Ferguson, Margaret Robertson. 1996. “Gubernatorial policy leadership in the fifty states.” Unpublished Dissertation, The University of North Carolina at Chapel Hill. 
Fording, Richard C., Neal D. Woods, and David Prince. 2002. "Explaining Gubernatorial Success in State Legislatures.” Presented at 2nd Annual Conference on State Politics and Policy: Legislatures and Representation in the United States, University of Wisconsin, Milwaukee, May 24-25.

Gray, Virginia, David Lowery, and Erik K. Godwin. 2007a. “Public Preferences and Organized Interests in Health Policy: State Pharmacy Assistance Programs as Innovations.” Journal of Health Politics, Policy and Law. 32 (1):89-129.

Gray, Virginia, David Lowery, and Erik Godwin. 2007b. “The Politics of Managed Care: Explaining Variations in State Health Maintenance Organizations Regulations.” Journal of Health Politics, Policy and Law. 32 (3):457-495.

Gray, Virginia, David Lowery, Erik Godwin, and James Monogan. 2005. “Incrementing Toward Nowhere: Universal Health Care Coverage in the States.” Paper Presented at the Annual Meeting of the American Political Science Association, August, Chicago.

Gray, Virginia, David Lowery, Matthew Fellowes, and Jennifer Anderson, 2005. “Understanding the Demand-Side of Lobbying: Interest System Energy in the American States.” American Politics Research. 33: 404-434.

Gray, Virginia, and David Lowery. 1998. "State Lobbying Regulations and Their Enforcement: Implications for the Diversity of State Interest Communities.” State and Local Government Review, 30 (2): 78-91.

Gray, Virginia, and David Lowery. 1996. The Population Ecology of Interest Representation: Lobbying Communities in the American States. Ann Arbor, Michigan: University of Michigan Press.

Gray, Virginia, and David Lowery. 1995a. “The Demography of Interest Organization Communities: Institutions, Associations, and Membership Groups.” American Politics Quarterly, 23: 3-32. Gray, Virginia and David Lowery. 1995b. “Interest Representation and Democratic Gridlock.” Legislative Studies Quarterly. 20: 531-552.

Grodzins, Morton. 1966. The American System: A New View of Government in the United States. 


\section{Chcicago: Rand McNally.}

Hecht, Stacey Hunter. 2001. “Laboratories or Lighthouses: The States, The Federal Government, and Social Policy Innovation.” Unpublished Ph.D. Dissertation, University of Minnesota.

Heinz, John P., Edward O. Laumann, Robert L. Nelson, and Robert H. Salisbury. 1993. The Hollow Core. Cambridge: Harvard University Press.

Johnson, Haynes and David S. Broder. 1996. The System: The American Way of Politics At the Breaking Point. Boston: Little, Brown \& Co.

Jones, Bryan D. and Frank Baumgartner. 2005. The Politics of Attention: How Governments Prioritize Problems. Chicago, IL: University of Chicago Press.

Karch, Andrew. 2007. Democratic Laboratories: Policy Diffusion among the American States. Ann Arbor: University of Michigan Press.

Keiderman, Eric. 2007. “State Immigration Laws Multiply. ” Stateline.org. Accessed at http://www.stateline.org/live/details/story?contentId=229930 on August 7, 2007.

King, James D. 2000. “Changes in Professionalism in U.S. State Legislatures.” Legislative Studies Quarterly. XXV: 327-343.

Kurtz, Karl T. 1992. “Understanding the Diversity of American State Legislatures.” Legislative Studies Section Newsletter. June:2-5.

Leech, Beth L., Frank R. Baumgartner, Timothy La Pira, and Nicholas A. Semanko. 2005. “Drawing Lobbyists to Washington: Government Activity and Interest-Group Mobilization.” Political Research Quarterly. 58:19-30.

Lowery, David, Virginia Gray, and Matthew Fellowes. 2005a. “Organized Interests and Political Extortion: A Test of the Fetcher Bill Hypothesis.” Social Science Quarterly, 86 (2): 368-385. Lowery, David, Virginia Gray, and Matthew Fellowes. 2005b. “Sisyphus Meets the Borg: Economic Scale and the Inequalities in Interest Representation,” Journal of Theoretical Politics, 17: 41-74. Lowery, David and Virginia Gray. 2001. “The Expression of Density Dependence in State Communities 
of Organized Interests.” American Politics Research, 29 (4): 374-391.

Lowery, David and Virginia Gray. 1998. “Representational Concentration and Interest Community Size: A Population Ecology Interpretation.” Political Research Quarterly, 51 (4): 919-944.

Lowery, David and Virginia Gray. 1997. “How Some Rules Just Don’t Matter: The Regulation of Lobbyists.” Public Choice, 91: 139-147.

Lowery, David and Virginia Gray. 1995. “The Population Ecology of Gucci Gulch, or the Natural Regulation of Interest Group Numbers in the American States.” American Journal of Political Science, 39: 1-29.

Lowery, David and Virginia Gray. 1994a. “The Nationalization of State Interest Group System Density and Diversity.” Social Science Quarterly. 75 (2): 368-377.

Lowery, David and Virginia Gray. 1994b. “Do Lobbying Regulations Influence Lobbying Registrations.” Social Science Quarterly, 75 (2): 382-384.

Macdonald, Stuart Elaine, and George Rabinowitz. 2001. "Issue Voting.” In International Encyclopedia of the Social and Behavioral Sciences, Neil J. Smelser and Paul B. Baltes, editors. Oxford, England: Pergamon.

Mettler, Suzanne. 2005. Soldiers into Citizens: The G.I. Bill and the Making of the Greatest Generation. New York: Oxford University Press.

Mintrom, Michael. 1997. “Policy Entrepreneurship and the Diffusion of Innovation.” American Journal of Political Science, 41: 738-770.

Mooney, Christopher Z. 1994. "Measuring U.S. State Legislative Professionalism: An Evaluation of Five Indices.” State and Local Government Review. 26:70-78.

Mossberger, Karen. 1999. “State-Federal Diffusion and Policy Learning: From Enterprise Zones to Empowerment Zones.” Publius, 29: 31-50.

National Conference of State Legislatures. 2007. “Immigrant Policy Project: Overview of State Legislation Related to Immigration and Immigrants in 2007.”Accessed at 
www.ncsl.org/programs/immig/2007StateLegislationImmigration.htm> on May 28, 2007.

Shipan, Charles R. and Craig Volden. 2006. "Bottom-Up Federalism: The Diffusion of Antismoking Policies from U.S. Cities to States.” American Journal of Political Science 50: 825-843.

Skocpol, Theda. 1992. Protecting Soldiers and Mothers: The Political Origins of Social Policy in the United States. Cambridge: Harvard University Press.

Skocpol, Theda, Marjorie Abend-Wein, Christopher Howard, Susan Goodrich Lehmann. 1993.

“Women’s Associations and the Enactment of Mothers’ Pensions in the United States.” American Political Science Review. 87: 686-701.

Squire, Peverill. 1992. "Legislative Professionalization and Membership Diversity in Stae Legislatures.” Legislative Studies Quarterly. XVII:69-79.

Squire, Peverill and Keith E. Hamm. 2005. 101 Chambers: Congress, State Legislatures, and the Future of Legislative Studies. Columbus, OH: Ohio State University Press.

Tews, Kerstin, Per-Olof Busch, and Helge Jorgens. 2003. “The Diffusion of New Environmental Policy Instruments.” European Journal of Political Research, 42: 569-600.

Thomas, Clive S. and Ronald J. Hrebenar. 1992. “The Integration of Interest Group Activity at the National, State and Local Level in the United States: Extent, Causes and Consequences.” Annual Meeting of the American Political Science Association, Chicago. September.

Truman, David. 1951. The Governmental Process. New York: Alfred A. Knopf.

Walker, Jack L., Jr. 1969. “The Diffusion of Innovations Among the American States.” American Political Science Review 63 (3, Sept.): 880-899.

Walker, Jack L., Jr. 1991. Mobilizing Interest Groups in America. Ann Arbor: University of Michigan Press.

Wawro, Gregory. 2000. Legislative Entrepreneurship in the U.S. House of Representatives. Ann Arbor, Michigan: University of Michigan Press.

Weissert, Carol S. 1991. "Policy Entrepreneurs, Policy Opportunists, and Legislative Effectiveness.” 
American Politics Research, 19: 262-274.

Weissert, Carol S. and William G. Weissert. 2002. Governing Health, $2^{\text {nd }}$ ed. Baltimore: Johns Hopkins. West, Darrell M., Diane Heith, and Chris Goodwin. 1996. "Harry and Louise Go to Washington: Political Advertising and Health Care Reform.” Journal of Health Politics, Policy, and Law. 21: 35-68. Wolak, Jennifer, Adam Newmark, Todd McNoldy, David Lowery, and Virginia Gray. 2002. “Much of Politics is Still Local: Multi-State Lobbying in State Interest Communities,” Legislative Studies Quarterly, 27: 527-556.

Wright, Gerald C. and Jon Winburn. 2002. "Patterns of Constituency-Legislator Policy Congruence in the States.” Presented at Second Annual Conference on State Politics and Policy: Legislatures and Representation in the United States, University of Wisconsin, Milwaukee, May, 24-25. 
Table 1: Pooled Guild-State Interest System Density Models with Federal Hearings Variables (n=600)

\begin{tabular}{|c|c|c|c|c|c|c|c|}
\hline \multirow{2}{*}{$\begin{array}{l}\text { Independent } \\
\text { Variable }\end{array}$} & \multicolumn{7}{|c|}{ Dependent Variable: No. of Organizational Lobby Registrations 1999} \\
\hline & Model 1 & Model 2 & Model 3 & Model 4 & Model 5 & Model 6 & Model 7 \\
\hline Sector & $0.72 * * *$ & $0.67 * * *$ & $0.65 * * *$ & $0.65 * * *$ & $0.65 * * *$ & $0.72 * * *$ & $0.38 * * *$ \\
\hline GSP & 6.62 & 6.36 & 6.20 & 6.17 & 9.36 & 10.25 & 5.23 \\
\hline Sector & $-0.38 * * *$ & $-0.35 * * *$ & $-0.33 * * *$ & $-0.33 * * *$ & $-0.31 * * *$ & $-0.35 * * *$ & $-0.11 * *$ \\
\hline GSP Sq. & -3.02 & -2.85 & -2.67 & -2.65 & -5.41 & -6.10 & -2.06 \\
\hline Party & $-0.08 * * *$ & $-0.09 * * *$ & $-0.09 * * *$ & $-0.09 * * *$ & $-0.10 * * *$ & $-0.09 * * *$ & -0.01 \\
\hline Competititon & -2.74 & -2.96 & -3.15 & -3.19 & -3.33 & -3.08 & -0.11 \\
\hline Size of & $0.30 * * *$ & $0.30 * * *$ & $0.29 * * *$ & $0.29 * * *$ & $0.19 * * *$ & $0.21 * * *$ & $0.25 * * *$ \\
\hline Agenda & 4.75 & 5.10 & 4.88 & 4.59 & 5.31 & 5.62 & 7.53 \\
\hline 1999 Fed. & -- & $0.15 \# \#$ & -- & -0.01 & -- & $0.47 \# \#$ & $0.35 \# \#$ \\
\hline Hearings & & 4.40 & & -0.12 & & 4.44 & 3.95 \\
\hline 1998 Fed. & -- & & 0.16 \#\#\# & 0.17 & $-0.15 \# \#$ & $-0.68 \# \# \#$ & $-0.53 \# \#$ \\
\hline Hearings & & & 4.38 & 1.61 & -2.51 & -0.51 & -4.74 \\
\hline Federal & & & & & $-0.32 \# \#$ & $-0.45 \# \#$ & $-0.47 \ldots \#$ \\
\hline Involvement & & & & & -4.84 & -6.33 & -7.89 \\
\hline Involvement & & & & & $0.58 \# \# \#$ & 0.80 \#\# & 0.75 \#\# \\
\hline x '98 Hearings & & & & & 7.29 & 8.63 & 9.83 \\
\hline Legislative & -- & -- & -- & -- & -0.02 & -0.03 & 0.00 \\
\hline Professionalism & & & & & -0.39 & -0.59 & 0.05 \\
\hline Professionalism & -- & -- & -- & -- & $0.11 *$ & $0.08 *$ & $0.14^{* * *}$ \\
\hline x '98 Hearings & & & & & 1.58 & 1.35 & 2.61 \\
\hline Constant & 41.21 & 33.84 & 36.41 & 36.65 & 49.94 & 46.43 & 11.54 \\
\hline R-Square & 0.47 & 0.49 & 0.49 & 0.49 & 0.54 & 0.55 & 0.72 \\
\hline
\end{tabular}

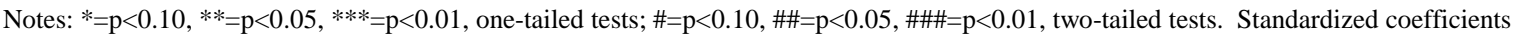
are presented with t-values reported below. Model 7 includes dummy variables for 49 states. 
Table 2: Pooled Guild Agenda Size Models with Federal Hearings Variables and State Dummies $(\mathrm{n}=600)$

\begin{tabular}{|c|c|c|c|c|}
\hline \multirow{2}{*}{$\begin{array}{l}\text { Independent } \\
\text { Variable }\end{array}$} & \multicolumn{4}{|c|}{ Dependent Variable: Size of State/Guild Policy Agenda, 1999} \\
\hline & Model 1 & Model 2 & Model 3 & Model 4 \\
\hline 1999 Fed. & 0.04 & -- & $-0.93 \# \#$ & $-0.55 \# \#$ \\
\hline Hearings & 0.76 & & -10.01 & -4.95 \\
\hline 1998 Fed. & -- & $0.14 \# \#$ & $1.03 \# \#$ & $0.37 \# \#$ \\
\hline Hearings & & 3.01 & 9.97 & 2.62 \\
\hline $\begin{array}{l}\text { Federal } \\
\text { Involvement }\end{array}$ & -- & -- & -- & $\begin{array}{l}-0.50 \# \# \# \\
-6.65\end{array}$ \\
\hline $\begin{array}{l}\text { Involvement } \\
\text { x '98 Hearings }\end{array}$ & -- & -- & -- & $\begin{array}{l}0.60 \text { \#\#\# } \\
6.15\end{array}$ \\
\hline $\begin{array}{l}\text { Legislative } \\
\text { Professionalism }\end{array}$ & -- & -- & -- & $\begin{array}{l}-0.36 \\
-1.59\end{array}$ \\
\hline $\begin{array}{l}\text { Professionalism } \\
\text { x '98 Hearings }\end{array}$ & -- & -- & -- & $\begin{array}{l}0.18 \text { \#\# } \\
2.54\end{array}$ \\
\hline Constant & 11.16 & -15.85 & 18.16 & 157.32 \\
\hline R-Square & 0.35 & 0.37 & 0.46 & 0.51 \\
\hline
\end{tabular}

Notes: $\#=p<0.10, \# \#=p<0.05, \# \# \#=p<0.01$, two-tailed tests. Standardized coefficients are presented with t-values reported below. Coefficients of state dummies are not shown. 


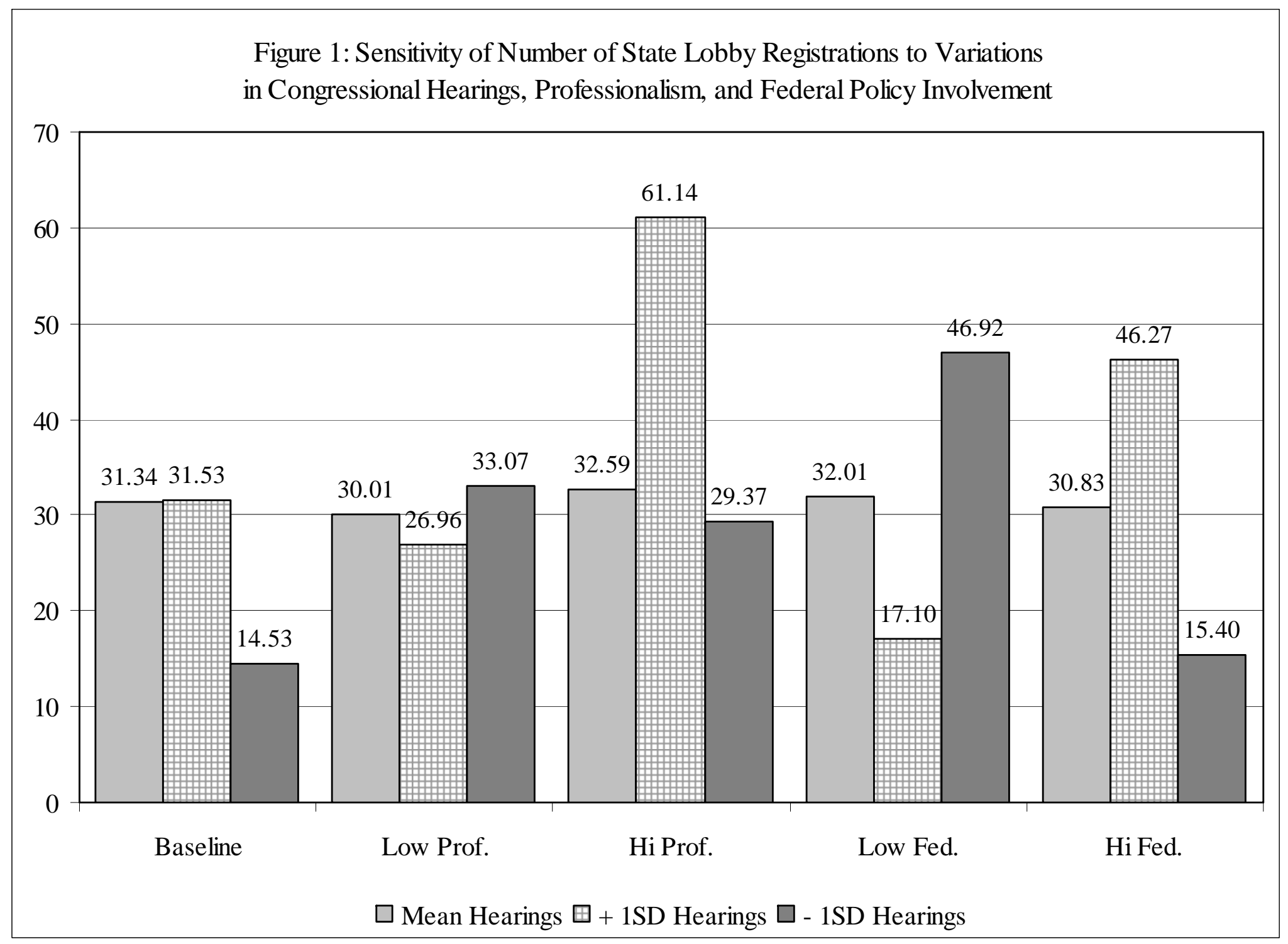


Appendix 1: State Interest Guilds and Policy Agendas Project Matches

\begin{tabular}{|c|c|}
\hline State Interest Guild & Policy Agendas Project Subtopic Codes \\
\hline \multicolumn{2}{|c|}{ Part A. Complete Match Available } \\
\hline Agriculture & 400-499, 529 \\
\hline Banking and Finance & $1501,1502,1504$ \\
\hline Civil Rights & 200, 201, 203-299 \\
\hline Communications & 1706, 1707, 1709 \\
\hline Education & $600-699$ \\
\hline Environment & $700-799$ \\
\hline Good Government & 2010, 2012 \\
\hline Government & 2000-2004, 2007-2009, 2011, 2030 \\
\hline Health & $300-399$ \\
\hline Insurance & 1505 \\
\hline Law & 1200-1206, 1210-1299 \\
\hline Military and Veterans & 1609,1612 \\
\hline Police and Fire & 1209 \\
\hline Natural Resources & 803,805 \\
\hline Tax and Government Regulation & 107 \\
\hline Transportation & $1000-1099$ \\
\hline Utilities and Energy & 802 \\
\hline Welfare & 1300-1399, 1525 \\
\hline Women’s Issues & 202, 508, 1208 \\
\hline \multicolumn{2}{|c|}{ Part B. Complete Match Not Available } \\
\hline \multicolumn{2}{|l|}{$\begin{array}{l}\text { Construction and Housing } \\
\text { Hotel, Restaurant, Liquor } \\
\text { Manufacturing } \\
\text { Religion and Churches } \\
\text { Small Business and Retail } \\
\text { Service: Other Firms } \\
\text { Sport, Amusement }\end{array}$} \\
\hline
\end{tabular}

Note. See www.policyagendas.org for complete descriptions of the policy subtopic codes. Matches were determined by assessing the substantive coverage of the state interest guilds and comparing with the corresponding policy agendas codes. In order to match, we required that the two sets of substantive codes cover the vast bulk of the substantive issues in the same area. Cases where there was some overlap, but not complete coverage, were declared not to match.

Boldface indicates 12 state interest guilds included in data set of this study. 